ISSN 1979-7450

\title{
PENGELOLAAN SUMBER DAYA AIR YANG BERKELANJUTAN DI KOTA SORONG
}

\author{
Hendrik Pristianto \\ Mahasiswa Program Magister Teknik Sipil Keairan Universitas Hasanuddin Makassar \\ Fakultas Teknik Universitas Al-Amin Muhammadiyah Sorong
}

\begin{abstract}
Abstrak
Pengelolaan Sumber Daya Air di Kota Sorong harus mengacu pada UU no 7 tahun 2004 dan PP No 42 tahun 2008 tentang Sumber Daya Air dimana prinsip keberlanjutan dalam pengelolaan menjadi faktor yang penting. Selain itu, juga perlu dikaji penerapannya di Kota Sorong adalah program IWRM, pengembangan Agrogokonservasi, River Restoration, Water Harvesting Management in Upland, pengkajian Retrding Bazin, Pengkajian mitigasi Bencana dengan Analisis Spasial Banjir dan Karakteristik Fisiografi, Wastewater dan Water Treatment Technology. Untuk lingkup Kota Sorong, masih sangat terbatas data-data dan hasil penelitian yang berkaitan dengan kondisi sumber daya air, misalnya beberapa sungai yang ada di Kota Sorong. Padahal masalah klasik di Kota Sorong berkaitan dengan sumber daya air adalah banjir tahunan yang disertai dengan krisis air bersih. Disatu sisi kelebihan air sampai meluap, disaat yang sama kekurangan air. Dari sisi kualitas air, batu sungai Remu yang ada data penelitiannya, itupun hanya pada daerah tengah sampai hilir.
\end{abstract}

Kata Kunci : Sumber Daya Air, Berkelanjutan

\section{PENDAHULUAN}

\subsection{Latar Belakang}

Air adalah salah satu dari sekian banyak sumber daya alam yang penting untuk kehidupan dan pembangunan. Peningkatan populasi dan pembangunan menyebabkan peningkatan kebutuhan terhadap sumber daya air. Sumber daya air terbagi menjadi : air permukaan (danau, situ, dam / reservoir, sungai), air tanah dan presipitasi / hujan.

Kota Sorong sebagai daerah yang sedang membangun, juga menempatkan pengembangan potensi sumber daya airnya dalam rangka memenuhi kebutuhan air bersih, mencegah intrusi air laut yang dapat mencemari kualitas air tanah, dan pengedalian volume banjir. Sebuah fakta yang bertolak belakang jika di daerah yang curah hujannya termasuk kategori tinggi, volume air tawar terbuang dengan cepat ke laut bersamaan dengan kejadian limpasan air banjir, tetapi pada saat yang bersamaan Kota Sorong mengalami krisis air tawar/air bersih.

\subsection{Permasalahan Yang Dihadapi}

Penurunan kualitas dan kuantitas sumber daya air di Kota Sorong disebabkan oleh beberapa faktor, antara lain :

1. Polusi / pencemaran / pengendapan terhadap sungai-sungai yang ada di Kota Sorong, khususnya Sungai Remu ,
2. kerusakan hutan / vegetasi pelindung cathment area dari sumber-sumber air sungai-sungai yang ada di Kota Sorong, khususnya Sungai Remu,,

3. peningkatan aktifitas pembukan dan pemakaian lahan pertanian yang menyebabkan perubahan fungsi daerah tangkapan air sungai-sungai yang ada di Kota Sorong, khususnya Sungai Remu,

\subsection{Lingkup Pembahasan}

Ruang lingkup yang akan dibahas dalam makalah ini adalah :

1. Apa dasar hukum upaya pengelolaan sumber daya air (SDA) yang berkelanjutan di Indonesia untuk diterapkan dalam pengelolaan SDA di Kota Sorong.

2. Bagaimana konsep Konservasi Sumber Daya Air (SDA) di Indonesia untuk diterapkan dalam konservasi SDA di Kota Sorong.

3. Bagaimana Kondisi Sumber Daya Air di Indonesia untuk dipakai sebagai pembanding kondisi (SDA) di Kota Sorong

4. Bagaimana upaya-upaya pengelolaan SDA di Indonesia Yang Berkelanjutan untuk dijadikan acuan dalam pemilihan model pengelolaan SDA di Kota Sorong. 
1.4 Maksud dan Tujuan Penulisan

Maksud dan tujuan penulisan makalah ini adalah :

1. Untuk mencari model pengelolaan sumber daya air yang sesuai untuk diterapkan di Kota Sorong dengan memakai konsep sustainable (Berkelanjutan)

2. Membuat rekomendasi kepada instansi terkait tentang model pengelolaan sumber daya air yang sesuai untuk diterapkan di Kota Sorong.

\section{PEMBAHASAN}

\subsection{Dasar Hukum Upaya Pengelolaan Sumber Daya Air Yang Berkelanjutan}

Dasar hukum dari upaya ini adalah :

a. Bahwa prinsip keberlajutan merupakan salah satu prinsip dari upaya Pengelolaan Sumberdaya Air, yang lainnya adalah kepentingan publik, kesatuan, keserasian, keadilan, otonomi, transparan dan akuntable.

b. Diawali dengan UU no 11/1974 yang konsentrasinya pada bidang Irigasi, kemudian diperbaharui dengan UU no 7/2004 yang konsentrasinya sudah pada Sumber Daya Air

c. Yang terbaru adalah PP no 42 tahun 2008, dimana "Pengelolaan Sumber Daya Air Yang Berkelanjutan" secara substantif tersirat pada pasal 2 dan pasal 66 ,

Dengan mengacu pada undang-undang atau peraturan pemerintah tersebut, Pemerintah Kota Sorong seharusnya membuat peraturan daerah (PERDA) khusus yang mengatur tentang Pengelolaan Sumber Daya Air Yang Berkelanjutan. Dalam prosesnya PERDA tersebut harus :

1. Dilakukan uji publik sebelum ditetapkan oleh PIHAK LEGISLATIF, hal ini untuk mencari masukkan yang komperehensif dari seluruh stakeholder SDA yang ada di Kota Sorong

2. Perlu disosialisasikan sebelum Perda tersebut diterapkan

\subsection{Konservasi Sumber Daya Air}

Konsep Konservasi Sumber Daya Air di Indonesia :

a. Dimaksudkan untuk menjaga keberlanjutan eksistensi daya dukung kapasitas, kapasitas tampungan, dan fungsi sumber daya air

b. Menimbulkan aktivitas restorasi dan kontinuitas sumber daya air, preservasi air, sebagaimana manajemen kualitas air dan pengendalian pencemaran air, yang mengikuti desain pengelolaan sumber daya air dari masing-masing sungai .

c. Kriteria dari konservasi sumber daya air menjadi referensi dalam spatial planning.

Untuk penerapan konsep konservasi sumber daya air di Kota Sorong, yang paling urgent saat ini adalah :

- Menjaga keberlanjutan eksistensi daerah tangkapan air (DTA) beberapa sungai yang mengalir di Kota Sorong. Ini penting karena terjadi potensi degradasi DTA sungai-sungai tersebut akibat kegiatan illegal loging, pembukaan lahan, dan galian pasir gunung. Hal ini nantinya diprediksi akan menyebabkan tingkat erosi yang tidak terkendali di bagian hulu, dan pendangkalan sungai di daerah pemukiman akibat deposit sedimen dari hulu dan permasalahan sampah.

\subsection{Kondisi Sumber Daya Air}

A. Di Indonesia

\section{Potensi Aliran Permukaan (Sungai)}

a. Potensi aliran permukaan di Indonesia adalah $1.789 \times 10^{9}$ $\mathrm{m}^{3} /$ tahun, dengan rincian $1.401 \times 10^{9}$ $\mathrm{m}^{3} /$ tahun , $557 \times 10^{9} \mathrm{~m}^{3} /$ tahun, dan jawa $118 \times 10^{9} \mathrm{~m}^{3} /$ tahun

b. Distribusi aliran permukaan terdapat pada 5.886 unit sungai dan 33 juta hectare danau, dam dan lahan basah

\section{Kerusakan sungai}

Sekitar 64 dari 470 watershed di Indonesia dalam kondisi kritis, tersebar dimana 12 area di Sumatera, 26 area di Jawa, 10 area di Kalimantan, 10 area di Sulawesi, 4 area di Bali, NTB, dan NTT, 4 area di Maluku dan 2 area di Papua. 


\section{Pencemaran sungai}

a. Kualitas air sungai di Indonesia sebagian besar telah dicemari oleh limbah domestik baik limbah industri maupun pertanian.

b. Hasil monitoring yang dilakukan di 30 provinsi pada tahun 2004, dengan sampel yang diambil 2 kali pertahun, mengindikasikan bahwa parameter DO,BOD,COD, fecal coli dan jumlah coliform maksimumnya berada di atas standar kelas 1 menurut PP no 82 / 2001.

4. Air Tanah

a. Monitoring terhadap 48 sumur di Jakarta yang dilakukan pada tahun 2004, mengindikasikan bahwa sebagian besar tercemar bakteri coliform dan fecal coli

b. Konsentrasi zat besi dan Mangan makin meningkat dimana pada beberapa sumur konsentrasi zat besinya di atas standar

c. Hanya 400 dari 4000 industri di Jakarta yang mempunyai waster water treatment plant.

\section{B. Di Kota Sorong}

\section{Potensi Aliran Permukaan (Sungai)}

Potensi aliran permukaan di Kota Sorong terdapat pada beberapa sungai, seperti Sungai Remu, Klagison, Klasaman, Rufei, Boswezen, Klablim, dan pada beberapa sungai kecil, rawa bakau dan lahan basah. Dari beberapa sungai tersebut, Sungai Remu menjadi objek yang paling dicermati karena selain berpotensi sebagai sumber air bersih, masih bisa dioptimalkan untuk kepentingan yang lebih besar apabila dibangun bendung/dam di hulu sungainya , misalkan untuk pengendalian banjir dan pembangkit listrik skala mikrohidro.

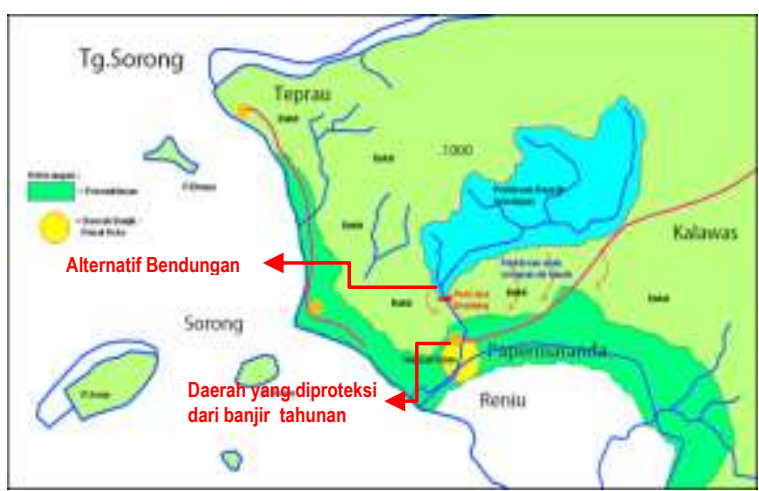

Gambar 1. Ilustrasi potensi Sungai Remu

\section{Pencemaran Sungai}

Penelitian terhadap tingkat pencemaran sungai diKota Sorong baru dilakukan terhadap Sungai Remu. Akan tetapi secara visual pencemaran kualitas air sungai-sungai di Kota Sorong disebabkan oleh limbah rumah tangga, industri rumah tangga, sampah dan kekeruhan akibat sedimentasi dari hulu sungai.

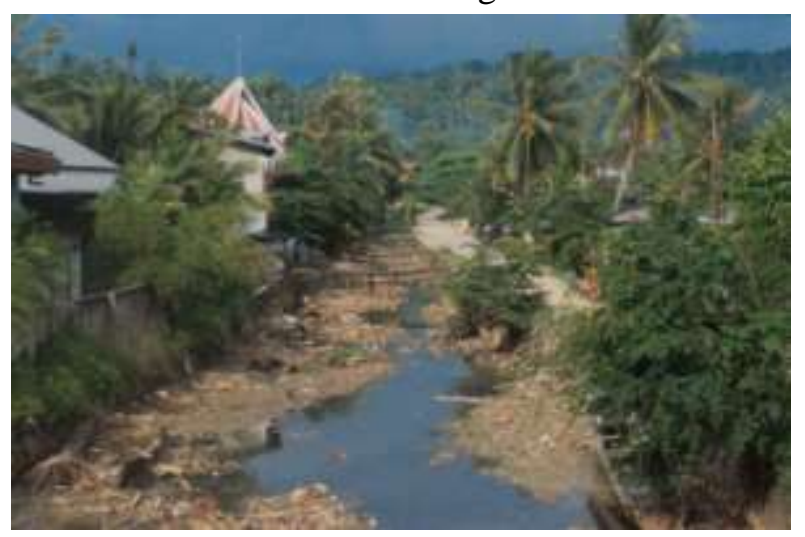

Gambar 2. Sampah di Sungai Boswezen

Adapun hasil penelitian terhadap kualitas air pada 4 titik di Sungai Remu adalah bahwa besarnya konsentrasi (Malawat, 2009) :

a. DHL pada titik $1=135,80 \mathrm{mg} / \mathrm{l}$, sedangkan titik 2, 3, dan 4 memiliki nilai over ranger (or) atau nilai diatas $19,900 \mu \mathrm{s}$.

b. TDS pada titik $1=7,558 \mathrm{mg} / \mathrm{l}$, titik $2=$ $16,312 \mathrm{mg} / \mathrm{l}$, titik $3=25,045 \mathrm{mg} / \mathrm{l}$, titik $4=27,200 \mathrm{mg} / \mathrm{l}$.

c. TSS pada titik $1=38,2 \mathrm{mg} / \mathrm{l}$, titik $2=$ $41,5 \mathrm{mg} / \mathrm{l}$, titik $3=50,3 \mathrm{mg} / 1$, titik $4=$ $55,8 \mathrm{mg} / \mathrm{l}$. 
d. $\mathrm{pH}$ pada titik $1=6,89 \mathrm{mg} / \mathrm{l}$, titik $2=$ $7,18 \mathrm{mg} / \mathrm{l}$, titik $3=7,18 \mathrm{mg} / \mathrm{l}$, titik $4=$ $7,18 \mathrm{mg} / \mathrm{l}$.

e. DO pada titik $1=6,10 \mathrm{mg} / \mathrm{l}$, titik $2=$ $6,21 \mathrm{mg} / \mathrm{l}$, titik $3=6,30 \mathrm{mg} / \mathrm{l}$, titik $4=$ $7,48 \mathrm{mg} / \mathrm{l}$.

f. BOD pada titik $1=12$, titik $2=12$, titik $3=12$, titik $4=12 \mathrm{mg} / \mathrm{l}$.

g. COD pada titik $1=100 \mathrm{mg} / \mathrm{l}$, titik $2=$ $110 \mathrm{mg} / \mathrm{l}$, titik $3=125 \mathrm{mg} / \mathrm{l}$, titik $4=$ $145 \mathrm{mg} / \mathrm{l}$.

h. Sulfat pada titik $1=10 \mathrm{mg} / \mathrm{l}$, titik $2=$ 12 , titik $3=12$, titik $4=12 \mathrm{mg} / \mathrm{l}$.

i. Klorida pada titik $1=100 \mathrm{mg} / \mathrm{l}$, titik $2=$ $112,8 \mathrm{mg} / \mathrm{l}$, titik $3=138,9 \mathrm{mg} / \mathrm{l}$, titik 4 $=289,2 \mathrm{mg} / \mathrm{l}$.

j. Seng pada titik $1=0,170 \mathrm{mg} / \mathrm{l}$, titik $2=$ $0,201 \mathrm{mg} / \mathrm{l}$, titik $3=0,208 \mathrm{mg} / \mathrm{l}$, titik 4 $=0,267 \mathrm{mg} / \mathrm{l}$.

k. Besi pada titik $1=0,083 \mathrm{mg} / \mathrm{l}$, titik $2=$ $0,100 \mathrm{mg} / \mathrm{l}$, titik $3=0,103 \mathrm{mg} / \mathrm{l}$, titik 4 $=0,136 \mathrm{mg} / \mathrm{l}$.

1. Mangan pada titik $1=\mathrm{tt}$, titik $2=\mathrm{tt}$, titik $3=\mathrm{tt}$, titik $4=\mathrm{tt}$.

m. Tembaga pada titik $1=0,021 \mathrm{mg} / \mathrm{l}$, titik $2=0,029$, titik $3=0,035$, titik $4=$ $0,042 \mathrm{mg} / \mathrm{l}$

n. Minyak dan Lemak pada titik $1=15,32$ ; titik $2=27,13$; titik $3=30,04$; titik 4 $=35,41 \mathrm{mg} / \mathrm{l}$.

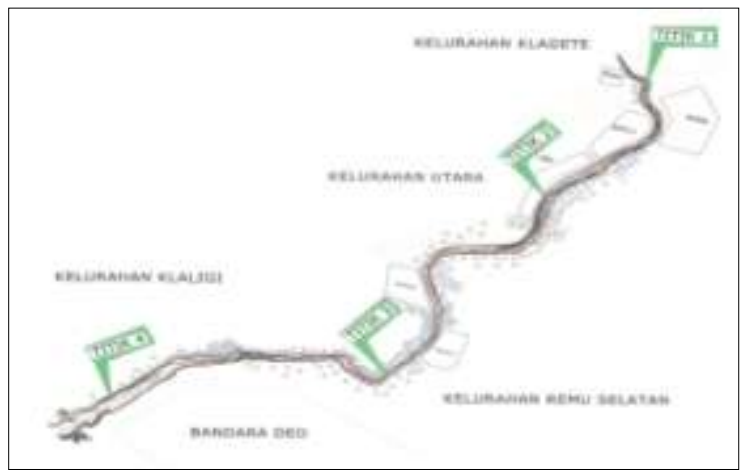

Gambar 3. Lokasi Titik Pengambilan Sampel Air Sungai Remu (Malawat, 2009)

Hasil laboratorium tersebut cukup besar bila dibandingkan dengan mutu baku yang di tetapkan dalam peraturan pemerintah No. 82 Tahun 2001, terutama di daerah hilir Sungai Remu yang memiliki konsentrasi yang cukup besar sehingga dari kualitas air Sungai Remu masuk dalam kualitas air kelas 4 (air untuk mengairi petanaman).
2.4. Upaya-Upaya Pengelolaan Sumber Daya Air Yang Berkelanjutan

1. INTEGRATED WATER RESOURCES MANAGEMENT (IWRM)

a. Maksud "integrated", bahwa kriteria umumnya adalah efisiensi ekonomi, fairness, dan sustainable on environment and ecology.

b. Kerusakan DAS $\rightarrow$ misalnya dapat dengan melakukan pendekaan memakai hydrological Model Application AGNPS 2002 (Agricultural Non-Point Source Pollution Model)

\section{Pengembangan Agrogeokonservasi}

a. Luas lahan kritis di Indonesia terus meningkat dari 11 juta ha pada tahun 1984 menjadi 46 juta ha pada tahun 2002. Reboisasi dan rehabilitasi lahan kritis tersebut sudah dilakukan sejak tahun 1970

b. Perlu konservasi dengan mempertimbangkan aspek ekosistem bentang lahan dan ekonomi masyarakat

c. Mengembangkan sistem pertanian konservasi dengan memperhitungkan kontrol geologi sebagai control keseimbangan alam.

d. Memanfaatan informasi geologi dalam penentuan kesesuaian lahan untuk optimasi budidaya pertanian.

e. Merehabilitasi lahan-lahan kritis dengan pertimbangan aspek geologis (longsor, erosi) diluar sistem pertanian.

f. Untuk memastikan luas lahan kritis di Kota Sorong perlu diadakan penelitian secara khusus dengan bekerjasama bersama pihak-pihak terkait. Ini dalam kaitannya untuk upaya pengelolaan, konservasi, optimasi budidaya pertanian, dan merehabilitasi lahan kritis tersebut.

3. Pengkajian Pemulihan Sungai (river restoration)

a. Sebagian besar sungai di Indonesia saat ini kondisinya rusak

b. Paradigma lama dalam pembangunan sungai : 
- "Bagaimana mengatuskan air permukaan secepatnya ke laut".

- Menekankan upaya konstruksi (sudetan, pelurusan, tanggul)

c. Watak sungai menjadi berubah dan menyebabkan banjir, kekeringan dan sedimentasi.

d. Paradigma baru : "Bagaimana menahan air sungai selama mungkindi kawasan hulu DAS, meresapkan dan mengalirkan secara perlahan"

e. Konsep ini telah diterapkan di banyak negara (Malaysia, USA, Jepang, Thailand, Jerman dll)

f. Teknologi yang diperlukan adalah : penanganan kawasan sempadan sungai, konservasi tanah \& air, ecoengineering.

Penerapan river restoration pada sungai-sungai di Kota Sorong perlu segera diambil langkah-langkah nyata mulai sekarang, alasanya :

a. Tingkat kekritisan sungai-sungai di Kota Sorong belum separah di Pulau Jawa khususnya.

b. Sungai di kota Sorong relatif tidak terlalu panjang, sehingga hal ini diharapkan lebih memudahkan dalam penangananya.

c. Kota Sorong akan semakin berkembang dan tidak menutup kemungkinan adanya pembangunan pemukiman dan industri sepanjang bantaran sungai di Kota Sorong akan semakin meningkat. Sehingga apabila proteksi dan restorasinya tidak dimulai dari saat ini, maka akan semakin sulit penanganannya.

4. Pengkajian Pemanenan Air di DAS hulu (Water Harvesting Management in Upland)

Contoh :

a. Curah hujan di Jawa tinggi, namun selalu kekeringan

b. Meningkatnya koefisien limpasan menyebabkan infiltrasi hujan mengecil sehingga cadangan air tanah berkurang

c. Air hujan perlu ditahan/ditampung pada lahan untuk memaksa air tinggal dan meresap ke dalam tanah secara perlahan.

d. Konsepnya mirip dengan Waduk Resapan, namun dalam skala kecil, sederhana dan lebih murah

e. Manfaatnya sebagai sumber air (pertanian, domestik), mengurangi banjir, mengurangi erosi tanah , menambah air tanah.

Kondisi di Kota Sorong :

a. Curah hujan lebih tinggi dari pulau Jawa, dari data BMG Bandara DEO Kota Sorong, curah hujan di Kota Sorong untuk periode 2007-2008, maksimal $=1028 \mathrm{~mm}$ dengan ratarata $369 \mathrm{~mm} / \mathrm{bulan}$.

b. Curah hujan merata sepanjang tahun, dengan banyaknya hari hujan adalah 12-27 hari per bulan.

c. Intensitas hujan untuk kala ulang 2 tahun adalah sekitar $9,4 \mathrm{~mm} / \mathrm{menit}$, yang dapat diartikan sebagai curah hujan dengan derajat hujan sangat deras (Sosrodarsono dan Takeda,2003)

d. Dengan potensi secara hidrologis tersebut, konsep pemanenan air di DAS bagian hulu untuk sungaisungai di Kota Sorong adalah suatu hal yang sangat LAYAK.

e. Hal tersebut didukung suatu fakta bahwa kejadian banjir tahunan di sepanjang sungai-sungai di Kota Sorong terjadai pada saat bersamaan juga terjadi krisis air bersih. Suatu hal yang perlu mendapatkan perhatian dari pihak-pihak terkait.

f. Dengan nilai manfaat bisa sebagai sumber air domestik, pertanian, menambah kuantitas air tanah , maka diharapkan Kota Sorong bisa mengatasi masalah krisis air bersih, karena AIR adalah hak dasar hidup bagi manusia secara pribadi maupun sosial.

g. Dan masih ada nilai manfaat banjir pengendalian banjir, maka diharapkan dengan konsep ini, dapat meminimalisir bencana banjir bagi masyarakat Kota Sorong. 
ISSN 1979-7450

5. Pengkajian Retarding Bazin

a. Kawasan terbangun menyebabkan meningkatnya koefisien limpasan sehingga limpasan besar dan infiltrasi kecil

b. Banyak fasilitas publik yang dapat dimanfaatkan sebagai retarding area guna mengurangi limpasan permukaan dan mengalirkan air ke dalam tanah

c. Retarding Area adalah :

- Kawasan publik yang dapat digunakan sebagai retarding area :1) tempat parkir; 2) lapangan; 3) taman; 4) jalan; 5) failitas umum lainnya

- Pemrakarsa : pemerintah, swasta, masyarakat

- Manfaatnya adalah untuk mengurangi banjir dan menambah suplai air tanah

6. Pengkajian Mitigasi Bencana Banjir Dan Kekeringan Dengan Analisis Spasial Banjir

a. Teknologi : Mikrozoning bencana (hazard mapping), analisis risiko, GIS, early warning system, analisis spasial, manajemen sumberdaya air

b. Output : Peta zonasi, informasi mudah, cepat dan akurat

c. Manfaatnya adalah membantu instansi terkait dalam pengambilan kebijakan, prioritas penanganan bencana, dan mengurangi dampak korban bencana

7. Pengkajian Mitigasi Bencana Longsor Dan Erosi Berdasarkan Karakteristik Fisiografi

a. Teknologi : Mikrozoning, aplikasi GIS, aplikasi remote sensing, early warning system

b. Output : Peta zonasi skala kecil-detail, analisis risiko, kesiapsiagaan,

c. Manfaatnya adalah membantu instansi terkait dalam pengambilan kebijakan dan perencanaan dan mengurangi dampak korban bencana

8. Wastewater Treatment Technology Tabel 1. Matrik "Recent Wastewater Treatment Technology'

\begin{tabular}{|c|c|c|c|}
\hline Wostewneer & Tectroiogs & \multicolumn{2}{|c|}{ Tysicil tectndogy } \\
\hline Orgavic degradsble & $\begin{array}{l}\text { Biological } \\
\text { process }\end{array}$ & 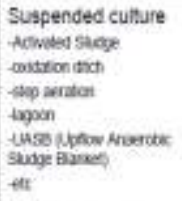 & 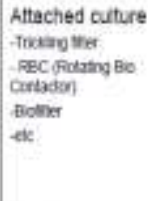 \\
\hline Inorganic & $\begin{array}{l}\text { Plyyscai and } \\
\text { charrical } \\
\text { process }\end{array}$ & \multicolumn{2}{|c|}{ 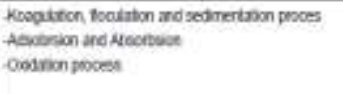 } \\
\hline 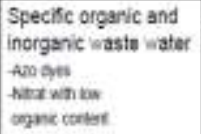 & $\begin{array}{l}\text { Specific } \\
\text { tratment }\end{array}$ & \multicolumn{2}{|c|}{ 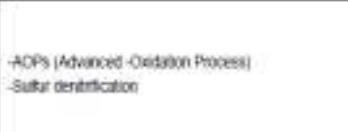 } \\
\hline
\end{tabular}

9. Water Treatment Technology

Tabel 2. Matrik "Recent Water Treatment Technology'

\begin{tabular}{|c|c|c|}
\hline Water charantisetic & $\begin{array}{l}\text { Tectimingy } \\
\text { pricess }\end{array}$ & Typical tactnobogr \\
\hline Frest waber & 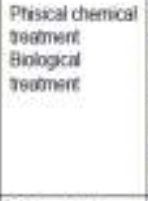 & 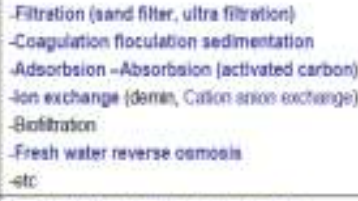 \\
\hline Brabsh waber & $\begin{array}{l}\text { Physical ind } \\
\text { cherical prosess }\end{array}$ & 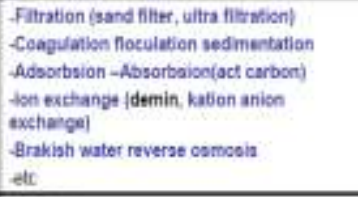 \\
\hline Soa wallor & $\begin{array}{l}\text { Desdination } \\
\text { crocess }\end{array}$ & 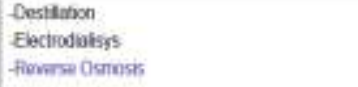 \\
\hline
\end{tabular}


ISSN 1979-7450

\section{PENUTUP}

\subsection{Kesimpulan}

Pengelolaan Sumber Daya Air Yang Berkelanjutan di Kota Sorong khususnya dan di Indonesia umumnya dilaksanakan :

1. sesuai dengan amanat UU No 7 / 2004 dan PP no 42 / 2008 tentang Sumber Daya Air

2. harus mengacu pada program IWRM, pengembangan AGRO KONSERVASI, River Restoration, Water Harvesting Management in Upland, pengkajian Retrding Bazin, Pengkajian mitigasi Bencana dengan Analisis Spasial Banjir dan Karakteristik Fisiografi, Wastewater dan Water Treatment Technology.

\subsection{Saran}

1. Dari berbagai program Pengelolaan SDA Berkelanjutan yang ada di atas, perlu diperluas penerapannya di Kota Sorong, karena kebanyakan sampel yang diambil masih di Pulau Jawa. Akan tetapi hal tersebut bisa dijadikan percontohan bagi Pengelolaan SDA Berkelanjutan di Kota Sorong.

2. Diperlukan penelitian/kajian tentang :

a. Luas lahan kritis dan upaya penangananya.

b. Upaya-upaya penerapan river restoration

c. Lokasi yang tepat untuk pemanenan air di DAS bagian hulu pada masing-masing DAS yang ada di Kota Sorong.

d. Lokasi-lokasi yang tepat untuk retarding Area

e. Untuk keperluan pemenuhan air bersih, PDAM harus mempunyai instalasi water treatment technology yang memadai.

f. Untuk pembangunan kawasan industri, harus dipersyaratkan harus memiliki instalasi wastewater treatment technology yang memadai http://www.science.org.au/events/indone sia/kardono.pdf. Didownload pada tanggal 16 Agustus 2008.

2. Lembaran Negara,2008. PP No 42 Tahun 2008 tentang Sumber Daya Air. http://www.legalitas.org/pp42-2008.pdf. Didownload pada tanggal 05 Nopember 2008.

3. Malawat, Qadry (2009), Dampak Aktivitas Masyarakat Kota Sorong Terhadap Tingkat Pencemaran Air Sungai Remu. Tugas Akhir Jurusan Teknik Sipil Universitas Al-Amin Muhammadiyah Sorong.

\section{DAFTAR PUSTAKA}

1. Kardono,2004. Water Resources Management in Indonesia, Condition and Its Environmental Technology. 